\title{
Short Communication: The phenomenon of nipah (Nypa fruticans) invasion in the Air Telang Protected Forest, Banyuasin District, South Sumatra, Indonesia
}

\author{
SYAIFUL EDDY ${ }^{1}$, MOHAMMAD BASYUNI ${ }^{2, \bullet}$ \\ ${ }^{1}$ Department of Biology, Faculty of Natural Sciences and Technology, Universitas PGRI Palembang. Jl. Jend. A. Yani No. 9/10 Ulu, Palembang 30251, \\ South Sumatra, Indonesia \\ ${ }^{2}$ Department of Forestry, Faculty of Forestry, Universitas Sumatera Utara. Jl. Tri Dharma Ujung No. 1, Kampus USU Padang Bulan, Medan 20155, \\ North Sumatra, Indonesia. Tel./fax. +62-61-8201920, `email: m.basyuni@usu.ac.id
}

Manuscript received: 26 September 2020. Revision accepted: 9 October 2020.

\begin{abstract}
Eddy S, Basyuni M. 2020. The phenomenon of nipah (Nypa fruticans) invasion in the Air Telang Protected Forest, Banyuasin District, South Sumatra, Indonesia. Biodiversitas 21: 5114-5118. Disturbed mangrove forests such as the Air Telang Protected Forest (ATPF) do not have plant formation as natural mangrove forests and tend to be invaded by Nypa fruticans locally called nipah. The purpose of this study was to describe the phenomenon of nipah invasion in ATPF as a result of anthropogenic activities and its effects. The field survey was carried out by determining several sampling points according to the actual conditions of the area using the Geographic Information System/GPS. During field survey, data were collected in the form of descriptions and documentation of forest conditions, especially the distribution of nipah plants along with interviews with the local communities. It was known that nipah invasion occurred in the ATPF area due to anthropogenic activities where nipah thrives in open areas, both in tidal and land zones, as well as in pond areas. The invasion of nipah will have an impact on disturbing the balance of mangrove forest ecosystem functions due to changes in the physical, chemical, and biological conditions of the environment. However, nipah has various benefits that can be used by the local community, including the leaves, stems, and fruit, as well as the presence of worms that are associated with the nipah plant.
\end{abstract}

Keywords: Anthropogenic, biological invasion, mangrove forest, Nypa fruticans

\section{INTRODUCTION}

Mangrove forest or also known as brackish forest, tidal forest, or coastal forest is one of the potential natural resources and has a unique ecosystem that plays a role in protecting coastal areas from various disturbances, as well as provides habitat for various coastal organisms (Wibowo and Handayani 2006; Fatoyinbo et al. 2008). Mangrove forest habitat which strongly influenced by salinity is inhabited by various types of plants, both true mangroves, and associated mangroves. Each species of mangrove plant has its level of tolerance to salinity, hence their distributional zonation varies from place to place (Laulikitnont 2014).

In natural mangrove forests, species of mangrove plants grow and occupy certain zones ranging from the near-shore zone to the near-land zone (the transition zone between a mangrove forest and lowland forest). Usually, the area closest to the sea is covered by Avicennia sp. and Sonneratia sp.; area more landward is dominated by Rhizophora sp., Bruguiera sp., and Xylocarpus sp.; and the transition zone between mangrove forests and lowland forests where nipah (Nypa fructicans Wurmb) and several other palm species are common (Bengen 2000; Basyuni et al. 2019).

The Air Telang Protected Forest (ATPF) is one of the protected coastal forest areas on the east coast of Sumatra Island which has experienced a lot of anthropogenic interference because it was converted partly into coconut plantations, oil palm plantations, ponds, and settlements (Eddy et al. 2017). The conversion of this forest to settlements and coconut plantations has been started in 1970s. Under the conditions of disturbed mangrove forests, such as ATPF, plant formations in various mangrove forest zones no longer follow the natural scheme like that of undisturbed mangrove forests. Plants that can reproduce and have high adaptability will dominate an area in a succession process of mangrove vegetation. Human intervention, changes in hydrographic conditions, interactions between species, changes in geomorphology, and the environment are known to affect succession of mangrove forests (Iftekhar and Saenger 2008; Cunha-Lignon et al. 2009).

The phenomenon of the nipah invasion can be witnessed in almost all mangrove forests along the east coast of South Sumatra, including in ATPF. This circumstance shows that the mangrove forests in this area have been most disturbed, especially due to anthropogenic activities. It has been reported that $N$. fruiticans is an invasive species that is able to suppress the growth of mangroves and other coastal species and has an explosive population due to high seed productivity and effective distribution of seeds whose spread is aggravated by anthropogenic activities (Numbere 2019). In addition, various studies across the world have indicated that nipah has escaped to areas outside its natural habitat, making it invasive (Duke 1991; Bacon 2001; Numbere 2018). 
This study aims to describe the phenomenon of nipah invasion in ATPF as the impact of degradation due to anthropogenic activities in this region. Apart from that, this research also describes the impact of the nipah invasion and the community's use of nipah. The results of this research are expected to provide information regarding the nipah invasion and its impacts so that it will be useful as part of the government's basis for making policies in mangrove forest conservation efforts, especially ATPF.

\section{MATERIALS AND METHODS}

\section{Study area}

Present study was conducted during October-December 2019 in the Air Telang Protected Forest (ATPF), Banyuasin District, South Sumatra Province, Indonesia which is a coastal protection forest in form of mangrove forest (Figure 1). ATPF has an area of approximately 12,660.87 ha (Forestry and Plantation Office of Banyuasin District 2010) and is situated directly adjacent to (i) Bangka Strait in the north, (ii) Muara Telang Sub-district in the south, (iii) Banyuasin II Sub-district and Muara Telang Sub-district in the east, and (iv) Banyuasin River in the west. This area has been converted by the community and companies into coconut plantations, oil palm plantations, and fishponds. Its strategic location, which is at the estuary of the Banyuasin River and facing the Bangka Strait, has led to conversion of this area. In addition, the government has planned to build the Tanjung Api-Api Special Economic Zone near this area.
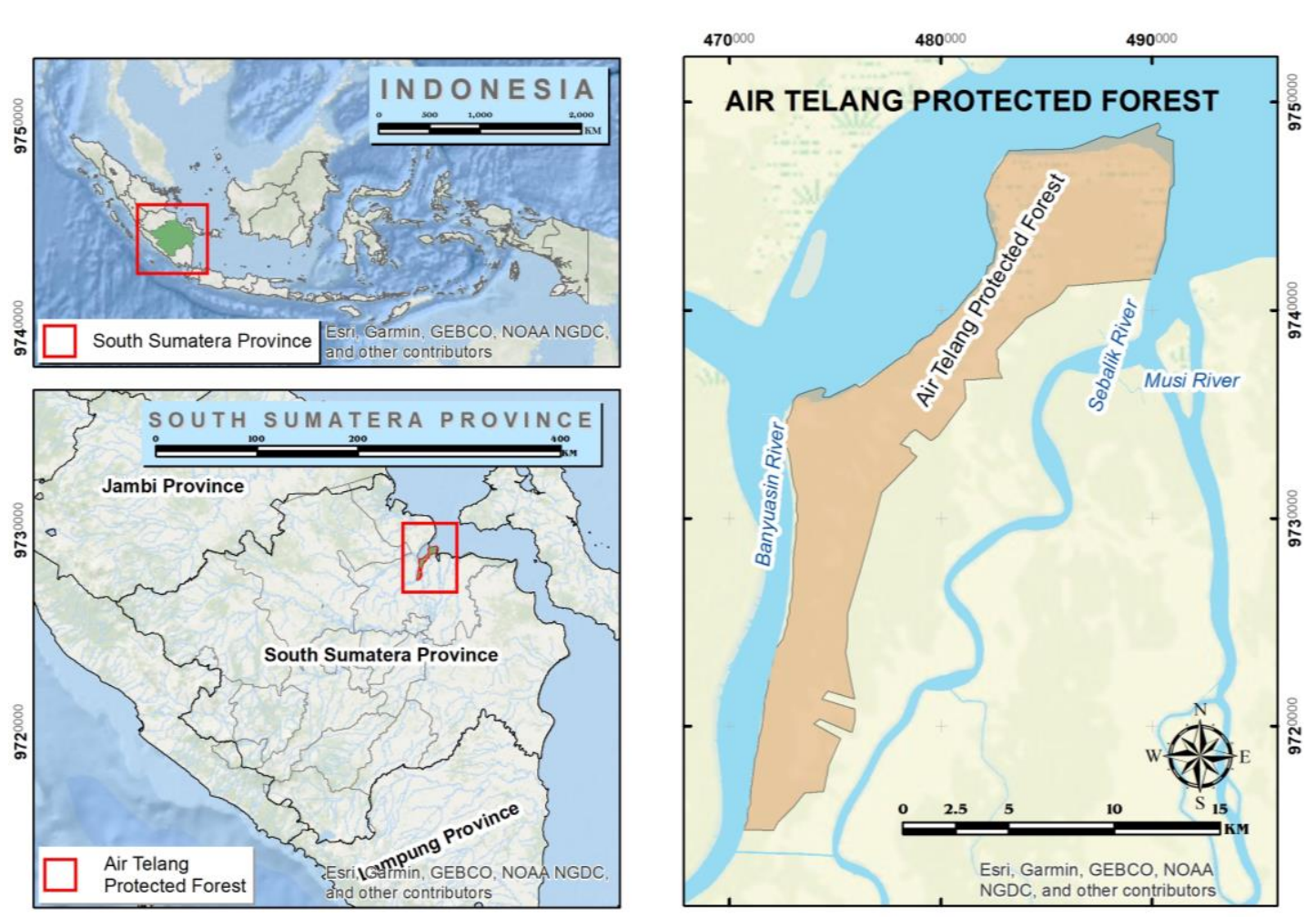

Figure 1. The study location at ATPF is in Banyuasin District, South Sumatra Province, Indonesia. Map coordinate system: UTM projection, zone $48 \mathrm{~S}$, datum WGS 1984

\section{Data collection and analysis}

Primary data in this study were obtained through field several sampling points according to the actual conditions of the area which were determined through coordinate points using the Geographic Information System/GPS (Table 1). Field survey data were collected in the form of descriptions and documentation of forest conditions, especially the distribution of nipah plants, both in primary and secondary forests; as well as shrubs. In addition, interviews were also conducted with the community regarding the existence of the nipah plant and its benefits for the community.

Secondary data were obtained through literature studies from relevant research results, both from journal articles and from books. The primary and secondary data obtained were analyzed by compiling the data to reveal the phenomenon of the nipah invasion in the ATPF area.

Table 1. Sampling coordinate points determined through the Geographic Information System (GPS) with coordinate points using the UTM system (Universal Transverse Mercator System) zone $48 \mathrm{~S}$

\begin{tabular}{llll}
\hline No & X coordinate & Y coordinate & Existing condition \\
\hline 1 & 474188 & 9719265 & Secondary forest \\
2 & 482571 & 9738843 & Secondary forest \\
3 & 475358 & 9734223 & Secondary forest \\
4 & 478367 & 9737877 & Primary forest \\
5 & 482014 & 9741432 & Primary forest \\
6 & 474835 & 9723392 & Coconut plantation \\
7 & 479451 & 9734076 & Coconut plantation \\
8 & 478415 & 9735853 & Fishpond \\
9 & 482343 & 9738413 & Fishpond \\
10 & 480547 & 9737243 & Open area \\
\hline
\end{tabular}
surveys. The field survey was carried out by determining 


\section{RESULTS AND DISCUSSION}

\section{Nipah invasion of ATPF}

Disturbed mangrove forests were usually dominated by $N$. fruticans stands, as is the case in the disturbed areas of ATPF. Nipah was found to thrive in open areas (logged or fire areas), both in tidal zones and on land; and areas that have been converted by the community, e.g. for fishponds (Figure 2).

During the study, it was noted that $N$. fruticans had started invading ATPF in almost all zones, from the near sea zone (tidal) to the near land zone. The condition of natural primary forest and disturbed primary forest in the tidal zone of ATPF was very different; some periphery of disturbed primary forest was overgrown by nipah in the leading formation (Figure 3). Nipah fruit bunches and lots (Figure 4) which float on water was being carried by tidal currents helping nipah to spread, especially in open areas and few mangrove stands.

\section{Nipah's ethnobotany at ATPF}

Based on the interviews with communities around ATPF, it was known that nipah leaves were widely used by the communities to thatch house roofs (Figure 5). The edible fruit could be eaten raw or made into processed food. Besides, nipah leaves were ideal for preparation of brooms and the stems were used by the communities to build bridges over trenches. Nipah root was also a suitable habitat for nipah worms, which is widely used by the locals as bait for fishing.
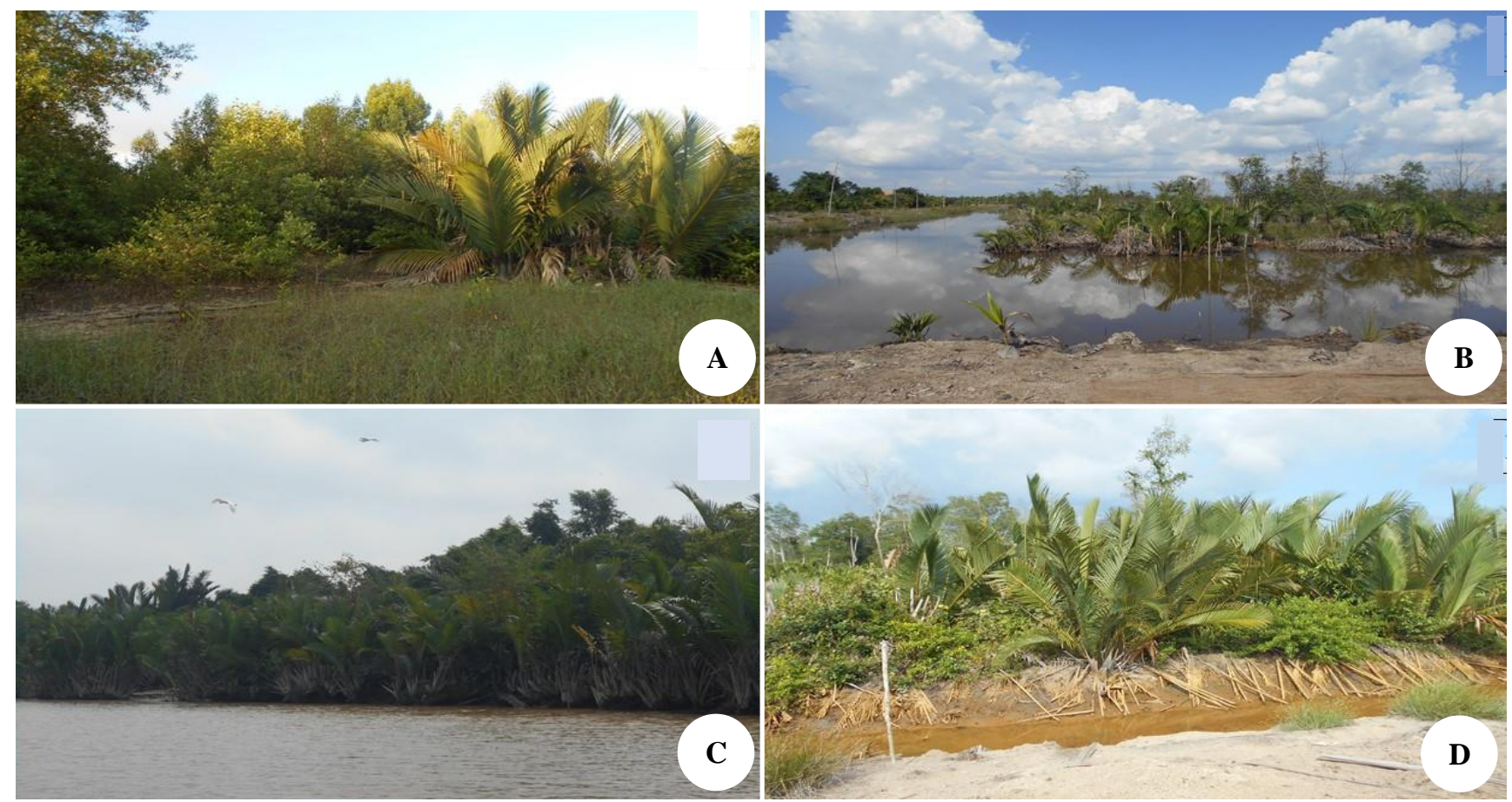

Figure 2. Nipah (Nypa fruticans) grown in various zones in Air Telang Protected Forest (ATPF), Banyuasin District, South Sumatra, Indonesia: logged-over land zone (A); tidal zone converted into ponds (B); logged-over tidal zone (C); and land zone made of drains (D)

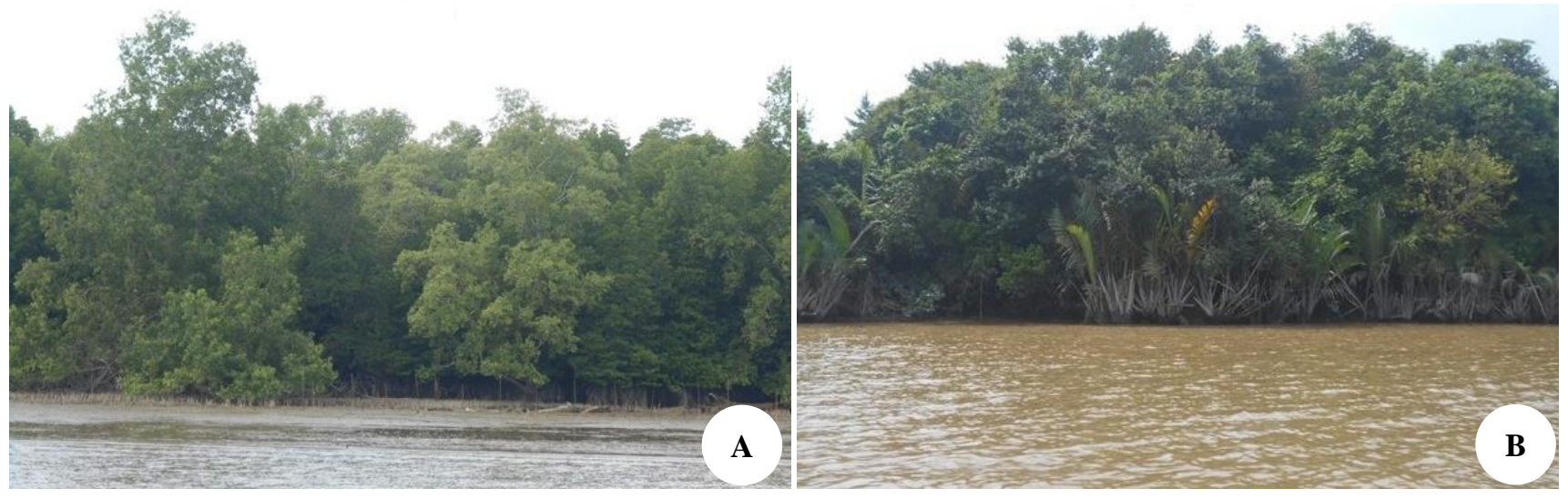

Figure 3. Condition of natural primary forest (A) and disturbed primary forest (B). Nipah formations grow in front of disturbed primary forest 


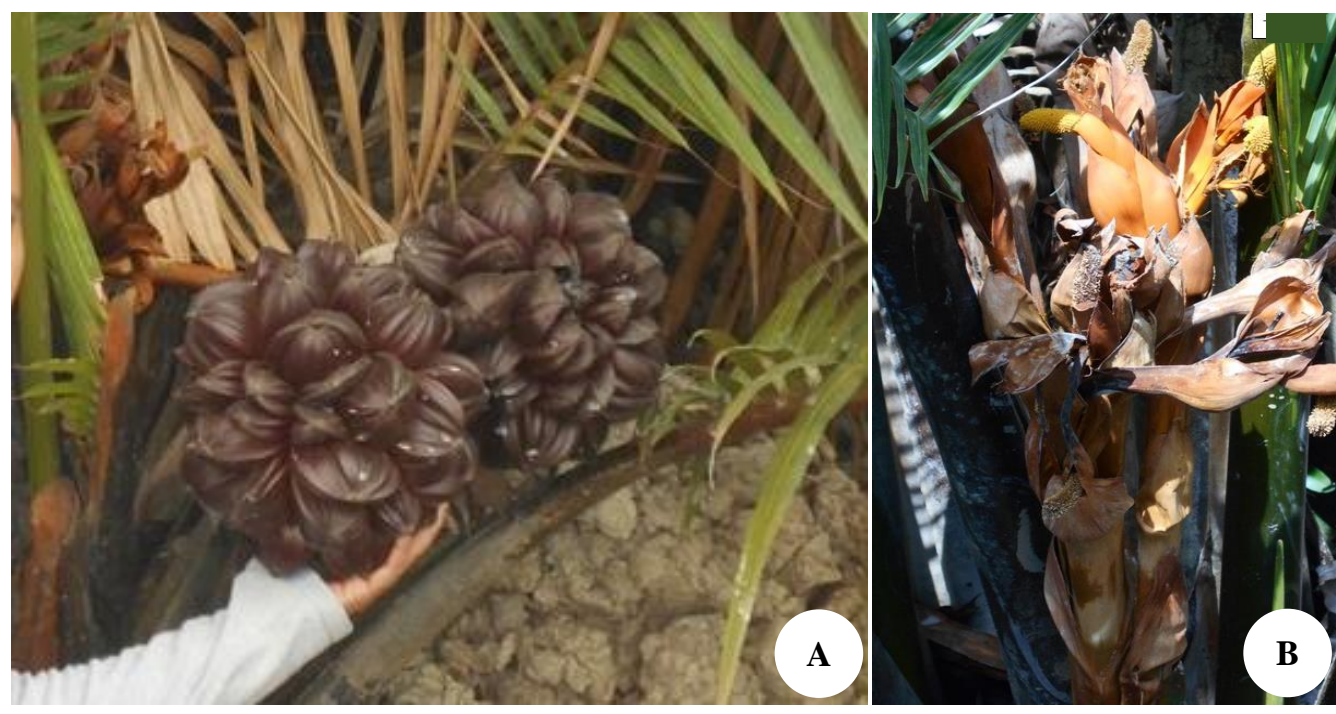

Figure 4. Nipah (Nypa fruticans) fruit bunches and lots (A), and the shape and structure of nipah flowers (B)

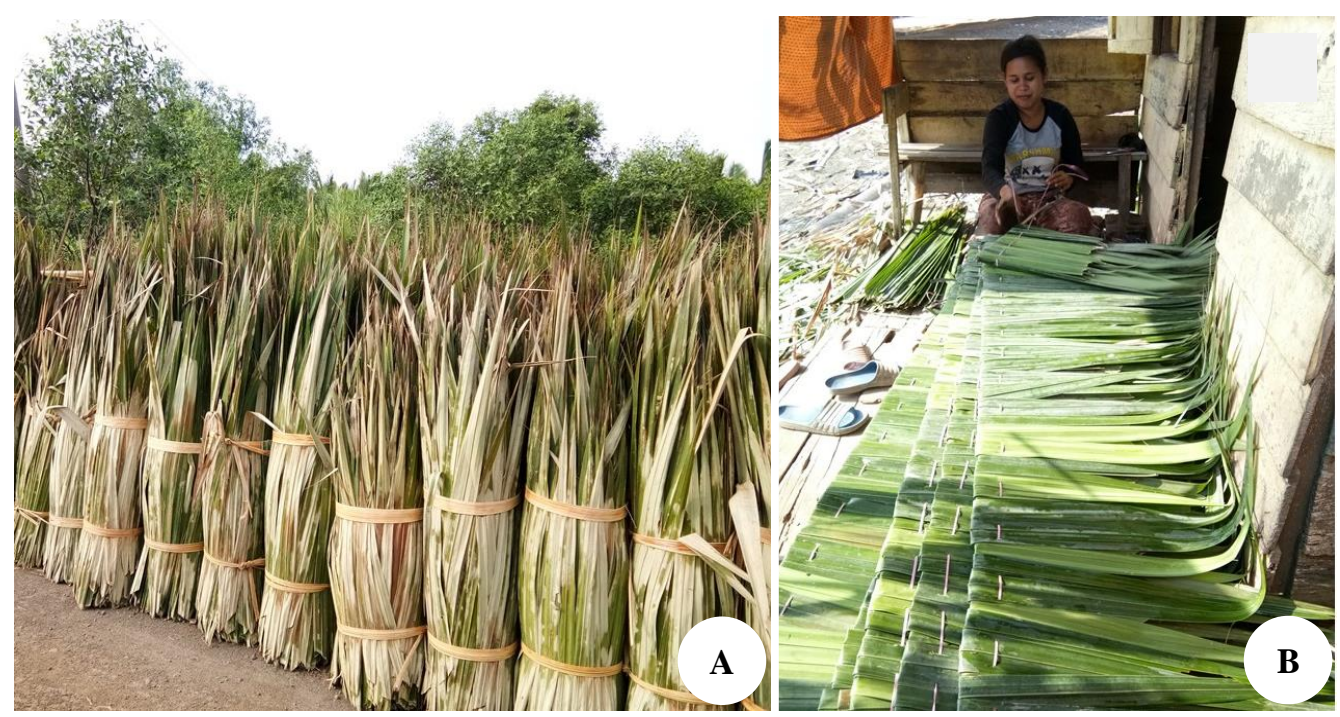

Figure 5. Nipah leaves collected by the community to be used as roofs of houses (A); Nipah leaf craftsmen are making roofs from nipah leaves (B)

\section{Discussion}

$N$. fruticans grows near the land zone bordering lowland forest in natural mangrove forest conditions. According to Laulikitnont (2014), N. fruticans prefers to grow naturally along the adjacent land zone (the transition zone between a mangrove forest and lowland forest) in undisturbed mangrove forest conditions. However, the presence of nipah in almost all mangrove forest zones indicates that the mangrove forest has been disturbed. Likewise, the disturbed ATPF conditions will easily be invaded by nipah in almost all zones, from the near sea zone (tidal) to the near land zone. According to Eddy et al. (2019), nipah was found in almost all sampling points in ATPF, both in primary forest, secondary forest, and disturbed primary forest, and was even able to dominate tree-level stands with an average Importance Value Index (IVI) of species of $89.9 \%$.
Nipah invasion in ATPF was found to be linked with forest degradation due to anthropogenic activities. In ATPF deforestation has resulted in increased open areas and reduced mangrove stands leading to reduced barriers of mangrove roots and tree. This in turn has facilitated nipah seeds to easily migrate along within open areas through tidal currents, develop a few stands at the beginning and become permanent dwellers (Akpakpan et al. 2012). Clements (1916) explained that the migration phase is the initial arrival of organisms to a disturbed location through the distribution of seeds and propagules where they can grow and adapt to the environment. The development of a species in a mangrove forest in the context of succession is strongly influenced by the availability of seeds and propagules as well as the presence of a medium of delivery in form of water currents. According to Djohan (2007), the development of pioneer species is determined by 
siltation/sedimentation, current and tidal patterns, as well as the availability of propagules and seeds from the surrounding forests.

Nipah invasion, especially in tidal areas, can replace the presence of mangroves and hinder the succession process of mangrove forests. Biswas et al. (2012) showed the dominant factors inhibiting the succession of mangrove forests are limited propagules due to damage to mature trees capable of producing seeds and the barrier to the propagation of propagules due to biological invasion of several species, including nipah. The loss of mangroves due to the dominance of nipah will result in changes in habitat both physically and chemically. This occurs because the invasion of nipah blocks the flow of water, thereby increasing sedimentation and blocking the flow of waste material. The pile of sludge due to sedimentation increases the amount of dirty sludge because it is mixed with the waste material, thereby reducing the physical and chemical quality of the soil. This results in inhibition of mangrove growth, disrupts the spawning process of aquatic organisms, and creates ecological problems (Numbere 2019). Mangroves are known to be used as excellent fish spawning grounds and the invasion of nipah can disrupt the stability of the aquatic ecosystem. According to Okpiliya et al. (2013) changes in mangrove habitat have an impact on decreasing fisheries productivity due to the nipah invasion gradually replacing mangroves. Although ecologically nipah invasion can disturb the balance of the mangrove forest ecosystem, as in case of ATPF, nipah has various benefits that can be used by the surrounding community. The parts of the nipah plant that are used by the community are the leaves, stems, and fruit, as well as the nipah worms associated with the nipah root. According to Eddy et al. (2018), the communities around ATPF utilize N. fruticans leaves to make roofs of houses and the fruit are eaten by the local people.

Gradual loss of mangrove is a tremendous cause of concern, especially for an Archipelago country with advancing challenges of climate change. Checking mangrove invasion of $N$. fruticans in mangrove forests like ATPF has to be focal point among forest management policies. Local communities are needed to be sensitized regarding impacts of anthropogenic deforestation and as well rewarded for sustainable management and monitoring of mangrove stands, including utilization of nipah based bioresources as a means to decrease its population. The results of this study can be used as a reference for the biological invasion of nipah in degraded mangrove forests. In addition, this study can contribute to the restoration and conservation of mangrove forests, especially ATPF.

\section{ACKNOWLEDGEMENTS}

Our deepest gratitude goes to Directorate of Research and Community Service, Ministry of Research and Technology and National Research and Innovation Agency,
Republic of Indonesia (No. 11/AMD/E1/KP.PTNB/2020) through the Post-Doctoral Research Scheme 2020.

\section{REFERENCES}

Akpakpan AE, Akpabio UD, Obot IB. 2012. Evaluation of physicochemical properties and soda pulping of Nypa fruticans frond and petiole. Elixir Appl Chem 45: 7664-7668.

Bacon PR. 2001. Germination of Nypa fruticans in Trinidad. Palms 45: 57-61.

Basyuni M, Hayullah A, Hamka M, Putri LAP, Baba S. 2019. Growth of salt-secretor and non-salt secretor mangrove seedlings with varying salinity and their relations to habitat zonation. IOP Conf Ser 236: 012050. DOI: 10.1088/1755-1315/236/1/012050.

Bengen DG. 2000. Pengenalan dan Pengelolaan Ekosistem Mangrove. Pedoman Teknis. Pusat Kajian Sumberdaya Pesisir dan Lautan IPB, Bogor. [Indonesian]

Biswas, SR, Khan MdSI, Mallik AU. 2012. Invaders' control on postdisturbance succession in coastal mangroves. J Plant Ecol 5: 157-166.

Clements FE. 1916. Plant Succession. Carnegie Institution of Washington Publication 242, Washington, DC.

Cunha-Lignon M, Coelho-Jr. C, Almeida R, Menghini R, Correa F, Schaeffer-Novelli Y, Cintrỏn-Molero G, Dahdouh-Guebas F. 2009. Mangrove forest and sedimentary processes on the south coast of Sao Paulo State (Brazil). J Coast Res 56: 405-409.

Department of Forestry and Plantation of the Banyuasin District. 2010. Reports on Disturbances Identification in Air Telang Protected Forest Area, Banyuasin. [Indonesian]

Djohan TS. 2007. Mangrove succession in Segara Anakan, Cilacap. Berk Ilmu Biol 6: 53-62. [Indonesian]

Duke NC. 1991. Nypa in the mangroves of Central America: Introduction or relief? Principes 35: 127-132.

Eddy S, Iskandar I, Ridho MR, Mulyana A. 2017. Land cover changes in the Air Telang Protected Forest, South Sumatra, Indonesia (19892013). Biodiversitas 18: 1538-1545.

Eddy S, Ridho MR, Iskandar I, Mulyana A. 2019. Species composition and structure of degraded mangrove vegetation in the Air Telang Protected Forest, South Sumatra, Indonesia. Biodiversitas 20: 21192127.

Eddy S, Rosanti D, Falansyah M. 2018. Keragaman spesies dan etnobotani tumbuhan mangrove di Kawasan Hutan Lindung Air Telang Kabupaten Banyuasin. Proceedings of the National Seminar on Applied Science and Technology. UIN Raden Fatah, Palembang, 20 October 2018. [Indonesian]

Fatoyinbo TE, Simard M, Washington-Allen RA, Shugart HH. 2008. Landscape-scale extent, height, biomass, and carbon estimation of Mozambique's mangrove forests with Landsat ETM+ and Shuttle Radar Topography Mission elevation data. J Geophys Res 113: 1-13.

Iftekhar MS, Saenger P. 2008. Vegetation dynamics in the Bangladesh Sundarbans mangroves: A review of forest inventories. Wetl Ecol Manag 16: 291-312.

Laulikitnont P. 2014. Evaluation of Mangrove Ecosystem Restoration Success in Southeast Asia. [Thesis]. University of San Francisco, California.

Numbere AO. 2018. Impact of invasive Nypa palm (Nypa fruticans) on mangrove forests in the Niger Delta. In: Makowski C, Finkl CW (eds) Coast in Crisis. Springer International Publishing, New York.

Numbere AO. 2019. Impact of invasive Nypa Palm (Nypa Fruticans) on mangroves in coastal areas of the Niger Delta Region, Nigeria. In Makowski C, Finkl CW (eds.), Impacts of Invasive Species on Coastal Environments. Springer International Publishing, New York.

Okpiliya FI, Effiong EB, Imoke E, Eja, Eja I. 2013. Mangrove forest ecosystem utilization and depletion: Implication for occupational changes in Calabar South, Nigeria. European J Sustain Dev 2: 149162.

Wibowo K, Handayani T. 2006. Pelestarian hutan mangrove melalui pendekatan mina hutan (silvofishery). J Tek Lingkungan 7: 227-233. [Indonesian] 